\title{
Effect of soil treatment on pest infestation and crop disease distribution in black soil fields with short rotation crops
}

\author{
I.D. Prymak, O.M. Yakovenko, M.V. Voytovyk, V.M. Karaulna, L.V. Yezerkovska, O.B. \\ Panchenko, Yu.V. Fedoruk, I.A. Pokotylo, I.A. Panchenko
}

\author{
Bila Tserkva National Agrarian University \\ Soborna Sq, 8/1, Bila Tserkva, Kyivska oblast, Ukraine \\ E-mail: Karaulnav@ukr.net, Mila.bogatyr@gmail.com
}

\section{Reveived: 10.01.2020 Accepted: 10.02.2020}

\begin{abstract}
We have established the influence of four tillage systems on pest distribution and development of diseases in cultivated cereals during three-year research (2017-2019) in the field stationary of the Bila Tserkva National Agrarian University, Ukraine (chernozem grain sprouting with five-course rotation). The population of turnip moth in winter wheat, spring barley, and soya was the highest under application of disk tillage, the lowest - under moldboard tillage. The moldboard treatment limited while the beardless and disk treatments stimulate the development of beet webworm in the cereal crops. The number of pests in soya, winter wheat, spring barley, and maize was higher under combined soil treatment compared to moldboard. We recorded no significant difference in pests towards tillage systems in sunflower crops. In soya, winter wheat and maize crops, the number of wireworm was significantly higher in molded than in molded cultivation; the opposite pattern was observed in the sunflower field, while for spring barley these values were at the same level. The distribution and development of root rot in cereal crops was higher in comparison with control, but this difference was insignificant in spring barley. The development of powdery mildew in spring barley crops was almost the same for these tillage options. In cereal crops, septoriosis lesions were almost at the same level in case of moldboard and combined tillage. Significant deterioration of phytosanitary condition at beardless and disk tillage resulted in significant reduction of crop rotation productivity in comparison with control. In the fields with combined and disk treatments, the productivity value was almost the same.
\end{abstract}

Keywords: Soil; Cultivation; Crop rotation; Agriculture lands; Diseases; Plant residues; Productivity

\section{Introduction}

Soil cultivation should contribute to increased crop yields and enhanced soil fertility. Obtaining environmentally friendly, economically viable, and competitive crop production requires scientists to conduct in-depth and comprehensive research on the ability to control pests in various methods, measures and tools of mechanical cultivation in crop rotations while reducing energy intensity of production (Prymak, 2019). Constant rise in price of energy ptoducts, fertilizers, pesticides, petrol, oil and lubricants makes the domestic agrarian looking for ways to reduce costs of agricultural production, one of which is to minimize soil tillage. However, scientific data on the impact of different tillage systems on the spread of diseases and pests are insufficient, and their results are in most cases contradictory. Due to urgent need for soil restoration, biologization and ecologization of domestic agriculture, and reduction of pesticide load on arable lands, one of the priority tasks is to develop crop rotation and mechanical tillage systems that would provide high phytosanitary effect.

Most scientists give preference to the deep ploughing as a way to limit the spread of diseases and pests in agrocenoses. Thus, I.L. Markov (2013) notes that early deep plowing is an effective measure to eliminate disease-causing agents (powdery mildew, head, rust, septoriosis, and fusariosis). In the experiments of I.M. Storchous (2013) ploughing increased the development of powdery mildew in wheat fields, while No-till technology caused the development of fusariasis (Markov, 2013). M.M. Klyuchevich (2014) gave preference to moldboard ploughing in comparison with no-metal and disk ploughing. In his experiments on ploughing of unfertilized areas he reduced the development of brown leaf rust by $10.7 \%$, powdery dew by $8.0 \%$, leaf septoriosis by $12.4 \%$, and root rot by $8.7 \%$. The intensity of root rot in wet years was $5-10 \%$ lower under ploughing, and in dry years it was lower under shallow beardless treatment. Soil tillage determined the phytosanitary condition of soil by $15-20 \%$ whereas the weather conditions by $60 \%$ (Timofeev et al., 2016).

According to some researchers, the development of diseases on wheat leaves was almost the same on fertilized plots after moldboard and beardless treatment (Krasilovets, 2010). In the experiments of M.M. Klyuchevich (2003) the distribution of septoriosis at the XI stage of organogenesis was 73.6-86.0\% under moldboard up to $20-22 \mathrm{~cm}$, when subsurface cultivating at the same depth $-78.4-90.9 \%$. When the depth of blade cultivator treatment decreased to $10-12 \mathrm{~cm}$, the distribution of septoriosis increased to $83.8-90.3 \%$. According to Krasilovets (2010), the development of diseases on wheat leaves is almost the same on fertilized areas with moldboard and beardless tillage. Some scientists attribute the growth of pathogens and pests at beardless, surface and no-tillage to the localization of plant residues in the surface soil layer and in the field (Markov, 2010; Polishchuk, 2014; Gavrilov, 2015; Pisarenko et al., 2008; Fedorenko \& Tribel, 2016).

Beardless tillage, especially with decreasing depth, causes an increase in flee beatles and wheat thrips (Timofeev et al., 2016). Numbers of ground beetle larvae were also significantly higher during subsurface cultivating and surface tillage (Khilevsky, 2013). Numbers of green bugs decreased with deep plowing by $70-90 \%$, shallow plowing (up to $10-12 \mathrm{~cm}$ ) - by $25-27 \%$, and pest numbers did not change with no-till technology (Alekhin, 2013). After harvesting corn for silage, plowing to a depth of 20-22 $\mathrm{cm}$ 
provided by 7-11 times less population of turnip moth larvae as compared to flat-cutting and surface tillage. The reason for this is the root remains localized in the field and in the surface soil layer, which attract female turnip moth for egg-laying (Krasilovets, 2010). The high efficiency of stubble removal and subsequent deep plowing in reducing the number of green bugs on fallen grains and monocotyledon weeds was indicated by Borovskaya et al. (2013). Noting the growth of the total number of insects at shallow ploughing by $12-64 \%$ compared to ploughing, the researchers point to a greater number of useful species (lady beetles, predatory bugs) when using subsurface soil cultivator (Timofeev et al., 2016). In the experiments of Uman National Horticulture University the defeat of crops at five-field crop rotation by disease-causing agents and pests was higher at moldboard tillage rather than at beardless treatment, and the increase of tillage depth improved the phytosanitary condition. Some researhers recommended plowing up to a depth of $15-17 \mathrm{~cm}$ for the soya, of $25-27 \mathrm{~cm}$ for spring wheat, barley, spring rape, and oil flax (Koval, 2019; Koval et al., 2018).

The purpose of our research was to establish the influence of four systems of soil cultivation on the distribution of pests and the development of diseases among cultivated plants and the productivity of field grain-and-pastoral five-field crop rotation scheme in the Right Bank Forest Steppe of Ukraine.

\section{Material and Methods}

Our research was conducted during 2017-2019 on the experimental field of the Bila Tserkva National Agrarian University. The experiment was organized under conditions of stationary field crop rotation, where it was supposed to study four systems of main tillage (Table 1) and four schemes of fertilization: zero - without fertilization, the first - 8 tons of manure $+\mathrm{N}_{76} \mathrm{P}_{64} \mathrm{~K}_{57}$; the second 12 tons of manure $+\mathrm{N}_{95} \mathrm{P}_{82} \mathrm{~K}_{72}$; the third - 16 tons of manure $+\mathrm{N}_{112} \mathrm{P}_{100} \mathrm{~K}_{86}$ for each hectare of arable land.

Table 1. Tillage and crop rotations systems.

$\begin{array}{cc}\text { Field Crops } & 1 \\ & \begin{array}{c}1 \\ \text { moldboard } \\ \text { (control) }\end{array}\end{array}$

1

2

3

4

5

p - plow, md. - mulching disk, dr. - deep ripper Soya

Winter

16-18 (p.)

wheat+siderate

white mustard

Sunflower

25-27 (p.)

Barley+siderate

white mustard

10-12 (md.)

10-12 (dr.)

25-27 (p.)

25-27 (dr.)
Soil tillage*

$\stackrel{2}{2} \stackrel{3}{\text { beardless }}$ combined

depth $(\mathrm{cm})$ and tillage system

We present the results of studies on pest and disease distribution from the first level (system) of crop fertilization in crop rotation, which provides the application of $\mathrm{N}_{30} \mathrm{P}_{40} \mathrm{~K}_{30}$ for soya, of $\mathrm{N}_{100} \mathrm{P}_{70} \mathrm{~K}_{50}$ for winter wheat, $\mathrm{N}_{15} \mathrm{P}_{15} \mathrm{~K}_{15}$ for two fileds of post-harvest mustard, 20 tons of manure $+\mathrm{N}_{50} \mathrm{P}_{50} \mathrm{~K}_{35}$ for sunflow*er, $\mathrm{N}_{50} \mathrm{P}_{40} \mathrm{~K}_{40}$ for barley, 20 tons of manure $+\mathrm{N}_{120} \mathrm{P}_{90} \mathrm{~K}_{100}$ for corn. The population of soya, winter wheat and spring barley were studied for four schemes of fertilizers. Soil under experience - black soil is typical deep, low humus, medium loam.

Repetition in the experiment is three times, the crop acreage was $171 \mathrm{~m}^{2}$ and the record plot was $112 \mathrm{~m}^{2}$. Moldboard was treated with a plough PLN-3-35, chisel GR- 3,4, disk - with a harrow BDT- 3. Calculation of turnip moth larvae was carried out in spring when the soil layer temperature was $15-20 \mathrm{~cm}$ through $10^{\circ} \mathrm{C}$. Eight soil samples were taken from each plot using a wooden square frame of $0.25 \mathrm{~m}^{2}(0.5 \times 0.5 \mathrm{~m})$ and the number of caterpillars was counted (Tribel et al., 2001).

Counting of beet webworm meadow moth larvae in cocoons after overwintering was performed on two diagonals of each area of the plots using a wooden square frame. Living and dead caterpillars were counted from 16 soil samples (Tribel et al., 2001). In spring, the number of wireworms larvae was determined from soil samples of $0.25 \mathrm{~m}^{2}$ area at a depth of $0.5 \mathrm{~m}$ (Omeluta et al., 1986). The helminthosporic root rot was taken into account in the phase of full sprouts. Samples were taken four times from one running meter of the row of cultivated plants in each area of experience. Dark brown spotting was counted on the E.E. Geschel scale in the phase of milky ripeness of winter wheat grain and spring barley on the upper second and third leaves (Tribel et al., 2001). We determined the defeat of upper three leaves and internodes by powdery dew in the phase of milky ripeness of winter wheat grain and spring barley on the E.E. Geshel scale. We also selected forty stems of cultivated plants in two non-contiguous repetitions for accounting (Omeluta et al., 1986). We defined the lesion of cereals with septoriosis in the phase of milky ripeness on the first four leaves on the E.E. Geshel scale. We selected 40 crop stalks in two non-contiguous repetitions for accounting (Omeluta et al., 1986). White rot was counted in the phase of soya and sunflower flowering. 10 samples were taken from 10 plants (Omeluta et al., 1986). 


\section{Results}

The narrow specialization of majority of forest-steppe farms in Ukraine for the production of cereals and oilseeds causes a widespread spread of pests, the development of which is usually related to the soil.

Minimization of mechanical soil tillage by replacing moldboard plowing with no-shallow, surface and zero tillage is accompanied by intensive pest development. The main source of pest spread is plant residues left in the surface layer of the soil and in the field after milling, shallow, superficial or zero tillage. As soil is the main habitat and breeding ground for pests, pest numbers and activity are highly dependent on cultivation methods and depth. The most common pests in our experiments were winter shovel, meadow moth, lined click beetle and common click beetle. In the fields of soya, winter wheat and spring barley the lowest infestation of winter shovel larvae was recorded after molding-up treatment, while the highest infestation was recorded during permanent disk plowing. Obviously, during the control treatment there is a mechanical destruction or damage to the caterpillars, and the pest larvae are also destroyed by entomophages, and the lower soil layers $(10-20,20-30 \mathrm{~cm}$ ) are brought to the field surface (Table 2 ).

Table 2. Infestation of crops by turnip moth larvae depending on soil tillage and fertilization systems, specimen $/ \mathrm{m}^{2}$.

\section{Tillage}

\section{Crops}

\section{fertilizers}

\section{moldboard} (control)
0.64

0.71

0.78

0.84

$\mathrm{N}_{60} \mathrm{P}_{80} \mathrm{~K}_{60}$

No fertilizers

$\mathrm{N}_{100} \mathrm{P}_{70} \mathrm{~K}_{50}$

$\mathrm{N}_{125} \mathrm{P}_{90} \mathrm{~K}_{70}$

$\mathrm{N}_{150} \mathrm{P}_{110} \mathrm{~K}_{80}$

No fertilizers

Barley

$\begin{array}{ll}\mathrm{N}_{50} \mathrm{P}_{40} \mathrm{~K}_{40} & 0.48 \\ \mathrm{~N}_{60} \mathrm{P}_{50} \mathrm{~K}_{50} & 0.56 \\ \mathrm{~N}_{70} \mathrm{P}_{60} \mathrm{~K}_{60} & 0.63\end{array}$

0.80

0.88

0.95

0.98

0.41

0.48

0.63
1.03

1.17

1.31

1.44

0.97

1.19

1.34

1.45

0.57

0.69

0.85

0.99 beardless

combined

0.71

0.81

0.90

0.99

0.91

1.05

1.18

1.25

0.32

0.42

0.52

0.60
1.16

1.32

1.49

1.63

1.02

1.23

1.40

1.50

1.07

Some research (Storchous, 2013; Korniychuk et al., 2014) indicate deterioration of conditions of overwintering turnip moth larvae after deep ploughing. In soya, winter wheat and spring barley crops, the number of pest larvae after moldboard was 0.74 , 0.90 , and 0.52 specimens $/ \mathrm{m}^{2}$, after beardless tillage - 1.24, 1.24, and 0.78; after no-till $-0.85,1.10$, and 0.47 ; after permanent shallow tillage $-1.40,1.29$, and 0.83 specimens $/ \mathrm{m}^{2}$. The $\mathrm{HIP}_{0.05}$ for the above crops was $0.09,0.08$, and 0.06 specimens $/ \mathrm{m}^{2}$. Thus, for the first two above-mentioned crops, this indicator was higher after chisel treatment by 67.6 and $37.8 \%$, for the combined one by 14.9 and $22.2 \%$, and after disk treatment by $89.2 \%$ and $43.3 \%$, respectively, than in control. In barley crops, the larvae numbers were $9.6 \%$ lower after moldboard-beardless tillage compared to moldboard, but this difference was not significant. Constant shallow and beardless exceeded the larvae number in control by $59.6 \%$ and $50.0 \%$ respectively.

Decrease of turnip moth population in spring barley agrocenosis at combined treatment in comparison with moldboard was obviously connected with deep plowing under the predecessor of this crop (sunflower) that allowed to remove vegetative remains of soya, winter wheat and other crops into deep soil layers $(15-25 \mathrm{~cm})$. With increasing fertilizer rates, the infestation of agrocenosis by turnip moth larvae also increased. When more fertilizers were applied, the number of turnip moth increased in winter wheat crops by $31.1 \%, 39.8 \%, 39.4 \%$, and $40.5 \%$ respectively in soya crops; by $22.5 \%, 49.5 \%, 37.4 \%$ and $47.1 \%$ in winter wheat crops; by $53.7 \%, 73.7 \%, 87.5 \%$, and $81.4 \%$ in spring barley crops. Thus, the negative impact of fertilizers on the number of turnip moth larvae in winter wheat agrocenosis increased after chisel and permanent shallow tillage, in spring barley crops it increased after combined tiilage, where it was most expressed. In agrocenoses of soya the influence of fertilizers was almost the same at all types of tillage.

Average pest population in agrophytocenosis of soya, winter wheat and spring barley was $1.06,1.13$, and $0.67 \mathrm{specimen} / \mathrm{m}^{2}$, respectively. A significant decrease of this indicator in spring barley was associated with crop rotation, where the predecessor was sunflower with the application of white mustard siderate. Thus, the systematic shallow disk plowing and constant variable depth beardless tillage provided better conditions for development and overwintering of the turnip moth than the variants with periodic plowing in crop rotation.

The types of soil tillage also had a rather noticeable impact on the turnip moth population. Moulding treatment limited the development of this pest, while beardless and disk treatments, on the contrary, stimulated its distribution. Obviously, turning the soil over with a plough, when the upper and lower parts of the cultivated layer of black soil are moved mutually, had a negative impact on wintering larvae in the surface layers of soil. In addition, the plough mechanically damages the cocoons of the turnip moths. Thus, in agrobioceneses of soya the pest number was the lowest and made $0.40 \mathrm{specimens} / \mathrm{m}^{2}$ after the moldboard. In case 
of beardless and mulching tillage this index increased by $27.5 \%$ and $20.0 \%$, respectively, and in case of combined tillage the deviation from control was within the limits of experience error (Table 3).

In agrocenoses of winter wheat, sunflower, spring barley, and corn the number of pests was higher at chisel processing by 20.7, $55.6 \%, 35.5 \%$, and $118.2 \%$, respectively, and at constant shallow tillage was higher by $17.2,38.9,29.0$, and $90.9 \%$, than in control. In combined treatment vaariant, this indicator was higher than in control, however, the difference between these values was insignificant, which was associated with deep plowing under oilseed crops.

Table 3. Infestation of crops by turnip moth and wireworm larvae under different tillage, specimen/m².

\section{Larvae infestation}

\section{Turnip moth}

\section{Crop}

rotation

\begin{tabular}{|c|c|c|c|c|c|c|c|c|c|c|}
\hline & $\begin{array}{l}\text { Moldboard } \\
\text { (control) }\end{array}$ & Beardless & Combined & Mulchig & HIP $_{0.05}$ & $\begin{array}{l}\text { Moldboard } \\
\text { (control) }\end{array}$ & Beardless & Combined & Mulching & HIP $_{\mathbf{0 , 0 5}}$ \\
\hline Soya & 0.40 & 0.51 & 0.43 & 0.48 & 0.05 & 0.25 & 0.40 & 0.31 & 0.39 & 0.05 \\
\hline $\begin{array}{l}\text { Winter } \\
\text { wheat }\end{array}$ & 0.58 & 0.70 & 0.63 & 0.68 & 0.05 & 0.18 & 0.32 & 0.23 & 0.30 & 0.04 \\
\hline Sunflower & 0.18 & 0.28 & 0.21 & 0.25 & 0.04 & 2.24 & 3.37 & 2.01 & 3.26 & 0.09 \\
\hline Barley & 0.31 & 0.42 & 0.36 & 0.40 & 0.04 & 0.71 & 0.90 & 0.76 & 0.88 & 0.06 \\
\hline Corn & 0.11 & 0.24 & 0.15 & 0.21 & 0.03 & 1.94 & 2.58 & 2.04 & 2.47 & 0.07 \\
\hline
\end{tabular}

lined click beetle and common click beetle

Tillage
During the surveys in sunflower and corn agrocenosis we recorded insignificant amount of turnip moth in spring, which is due to relatively early harvesting of winter wheat and spring barley and planting of green mass of siderates. Females of the pest lay eggs in July-August, when winter wheat and barley are no longer in the field, and therefore the larvae of the second generation are deprived of a source of food. The highest density of turnip moth population was recorded in winter wheat field, especially at disk and beardless processing ( 0.68 and 0.70 specimen $/ \mathrm{m}^{2}$, respectively), which is associated with the late harvesting of the predecessor (soya) and the presence of good forage base for the pest and conditions of transition to wintering. Significant decrease in pest numbers after deep ploughing occurred due to mechanical damage to the cocoons and their movement by the plough to the lower parts of the arable soil layer.

At the experimental sites we found Agriotes larvae, which feeding on germinated seeds and root system of Koeleria plants. While in our experimental variants the small weeds were dominataed and perennial grains were almost absent, we did not observe wide distribution of click beetle larvae.

In all agrocenoses, the number of wireworm larvae is significantly higher after beardless and disk treatment in comparison with moldboard (Table 3). In agrocenoses of soya, winter wheat, and corn, the moldboard tillage caused a greater reduction in pest population than combined treatment. The opposite pattern was observed in sunflower crops, while we established the equivalence of both tillage systems for spring barley interms of pest abundance. Thus, after chisel and disk treatments, the number of wireworms increased by $60.0 \%$ and $56.0 \%$ in soya crops, by $77.8 \%$ and $66.7 \%$ in winter wheat crops, by $50.4 \%$ and $45.5 \%$ in sunflower crops, by $26.8 \%$ and $23.9 \%$ in spring barley crops, and by $33.0 \%$ and $27.3 \%$ in corn crops, respectively, compared with the control.

The number of click beetle larvae decreased after ploughing due to mechanical destruction by the plough and further damage from the birds and insects - spiders, ants, and bedbugs in the surface soil layer after turning over the treated layer. The number of wireworm larvae has decreased after the cultivated plants. Substantial increase in the number of click beetle larvae after milling and disk treatment after dicotyledonous crops is also due to increased infestation of Koeleria family weeds (rye brome, green foxtail, wild foxtail millet, barnyard millet).

The results of our previous studies convince us that after moldboard tillage the infestation was much lower, and the share of dicotyledonous weeds, such as redroot pigweed, fat hen, chickweed, etc. was increasing (Primak et al., 2018). It has been established that localization of plant residues in the upper soil layer after milling and disk treatment leads to the spread of pathogenic organisms. Thus, the distribution of helminthosporiotic root rot in the phase of winter wheat quenching was by 7.1 and $8.0 \%$ higher, respectively, and in spring barley it was higher by 5.1 and $6.0 \%$ than in the control. The disease development also had a similar pattern (Table 4).

The distribution and development of root rot in agrocenosis of grain spiked crops was higher after combined treatment than after moldboard. In spring barley sowing this difference was insignificant, which is obviously due to deep cultural plowing under their predecessor plants. Better humidification of arable and meter soil layers after ploughing and milling also limits the spread and development of the disease in our opinion by providing good turgor to plants.

We recorded the manifestation of helmintosporiosis in the form of dark brown spots on the leaf surface of cereal crops. In winter wheat crops, the manifestation and development of the disease was higher with the use of beardless treatment by 6.0 and $4.7 \%$, with the use of moldboard-beardless treatment by 1.2 and 1.2 , and with mulching treatment by 6.8 and $5.9 \%$ relative to control. $A$ similar pattern was recorded in spring barley crops when using moldboard and combined treatment, but the difference was statistically insignificant.

During the earing phase of winter wheat, the distribution of powdery mildew when using chisel, combined, and shallow treatment was higher by $1.26,1.06$, and 1.31 times respectively compared to the control. The disease development in spring barley crops was practically at the same level with the use of moldboard and combined treatment, whereas with beardless and disk treatment it was 2.6 and $3.0 \%$ higher relative to the control. 
Table 4. Disease distribution in cereal crops depending on tillage systems, \%.

$\begin{array}{lllll}\text { Crops tillage } & \text { Helmintosporic root rot } & \text { Dark brown spotting } & \text { Sowdery mildew }\end{array}$

Distrubution Development Distrubution Development Distrubution Development Distrubution

Development

$\begin{array}{lccccccc}\begin{array}{l}\text { Moldboard } \\ \text { (Control) }\end{array} & 17.5 & 10.5 & 18.7 & 11.6 & 14.8 & 8.5 & 22.4 \\ \\ \text { Beardless } & 24.6 & 15.1 & 24.7 & 16.3 & 18.7 & 11.2 & 26.5\end{array}$

Winter

weat

Septoriosis was widespread in crops sown with yellow-brown spots on both sides of the leaf plate, where dark brown small picnics were formed over time. In the case of moldboard and beardless tillage, the level of spread and development of the disease was almost the same; in case of beardless disk tillage the disease rate was much higher with respect to control.

The most favorable conditions for the development of the causative agent of white rot in soya crops were observed in the phases of the beginning of bean formation and its ripening. The lesion was characterized by typical signs, especially in the lower part of the stem of the crop, near the root neck. Cotton-like white patina was observed on the stem of plants, the core tissue was rotting, and only the vascular-fibrous bundles remained intact. Leaves of the affected plants lost their turgor, withering and finally dried up.

Ploughing under soya and its predecessor with moldboard tillage was characterized by the highest damage of grain legumes and corn sowing. Under beardless and shallow tillage the manifestation of white rot in soya crops increased by $2.09 \%$ and $2.68 \%$, respectively, and disease development increased by $2.30 \%$ and $2.82 \%$ relative to control at $\mathrm{HIP}_{0.05} 0.94$ and $0.81 \%$. In corn sowing the most effective treatment was moldboard processing, at which the distribution and development of white rot was significantly lower $-3.10 \%$ and $2.82 \%$, respectively, that was $1.97 \%$ and $1.59 \%$ less than with bearless tillage and 2.89 and $2.32 \%$ lower than at disk tillage. Application of deep plowing (combined treatment) even once per rotation decreased the soya and sunflower infestation compared to moldboard treatment, but this difference was insignificant. The crop rotation productivity was 4.43, 3.90, 4.30 , and $3.83 \mathrm{t} \mathrm{ha}^{-1}$ of dry matter under moldboard, beardless, combined, and disk treatments at $\mathrm{HIP}_{0.05} 0.41 \mathrm{t}$ ha ${ }^{-1}$, respectively (Table 5).

Table 5. Infestation of soya and sunflower crops with white rot depending on soil tillage systems, $\%$.

\section{Crops}

$$
\text { Soya }
$$

\section{Tillage}

Molbroad (control)

Beardless

Combined

Shallow

$\mathrm{HIP}_{0,05}$

Molbroad (control)

\section{Distribution}

6.05

8.14

6.81

8.73

0.94

3.10

\section{Indicators}

Development

5.38

7.68

5.91

8.20

0.81

2.82 


\section{Conclusions}

1. The population of turnip moth in winter wheat, spring barley and soya was the highest when using disk tillage, the lowest - when using moldboard treatment. This value was slightly lower in spring barley fields when using moldboards-beardless tillage compared to moldboard. The abundance of larval population increases along with the rate of fertiliser applied.

2. The moldboard tillage limited whereas the beardless and disk tillage stimulated the development of beet webworm in all the studied crops. The number of pests in soya, winter wheat, spring barley, and maize crops was higher during combined treatment in comparison with moldboard. In sunflower crops we did not observe the significant differences.

3. The number of wireworm was significantly higher at chisel and shallow tillage compared to moldboard. In soya, winter wheat, and maize crops, the number of wireworm was significantly higher in case of moldboard-beardless reatment compared with moldboard; in sunflower crops the opposite pattern was observed, while in spring barley crops the number of pests was at the same level using these soil tillage techniques.

4. Pest infestation of cultivated plants was significantly higher with the use of disk and beardless tillage. The distribution and development of root rot in cereals spiked crops was higher with the use of disk and beardless tillage, however, in spring barley crops this difference was insignificant. The development of powdery mildew in spring barley crops was equal under these types of soil tillage. In sowing cereal spiked crops, the septoriosis lesions were almost at the same level when using moldboard and combined tillage.

\section{References}

Alekhin, V.T. (2013) Problems of control of cereal flies. Plant protection and quarantine, 8, 26-28 (in Ukrainian).

Borovskaya, I. Yu., Luchna I. S., Sokol T.V., Babushkina T.V., Nizka I.M. (2013) Cinderella on cereals. The Ukrainian Farmer, 11, 6264 (in Ukrainian).

Fedorenko, A.V., Tribel, S.O. (2016) Bread beetles. Reproduction outbreaks, malpractice, population restriction system. Quarantine and plant protection, 11, 5-8. (in Ukrainian).

Gavrilov, S.O. (2015) Warnings about mini-bodies. Farmer, 5, 20 -23.

Khilevsky, V.A. (2013), The bread beetle in the North Caucasus. Plant protection and quarantine, 8, 21-23. (in Russia).

Klyuchevich, M.M. (2003) The Role of Anthropogenic Factors in Increasing the Resistance of Winter Wheat to Septoria in AgroEnvironmental Polesie. GAU Bulletin, 1, 270-278 (in Ukrainian).

Klyuchevich, M.M.(2014) Influence of soil cultivation and fertilizers on the development of mycosis of winter triticale in Polissya of Ukraine. Interagency thematic scientific collection. Protection and quarantine of plants. Kyiv, 60, 144-150 (in Ukrainian).

Korniychuk, M.S., Vinichuk, T.S., Parminska, L.M. (2014) Protection of field crops from pests and diseases by technologies of organic production. Proceedings of the National Science Center "Institute of Agriculture of NAAS", 1-2, 98-110. (in Ukrainian).

Koval, G.V. (2019) The level of intensity of soil tillage and phytosanitary condition of crops of short rotation crop rotation of RightBank Forest Steppe of Ukraine. Thesis of Doctoral Dissertation. Uman (in Ukrainian).

Koval, G.V., Yeshenko, V.O., Kaliyevsky, M.V. Naklyoka, Y.I. (2018) Influence of the intensity of basic tillage on the Distrubution of pests in the crops of spring crops of five-field rotation. Taurian Scientific Bulletin, 103, 62-69. (in Ukrainian).

Krasilovets, Y.G. (2010) Optimization of phytosanitary safety system of cereals. Handbook of the Ukrainian farmer (in Ukrainian)

Markov, I.L. (2010) Rape diseases. Agribusiness today, 15, 4-6 (in Ukrainian).

Markov, I.L. (2013). Agrotechnical techniques prevent disease. Agribusiness today, 9, 26-28 (in Ukrainian).

Omeluta, V.P. (1986) Accounting for pests and diseases of crops. Kiev: Urozhay (in Ukrainian).

Pisarenko, V.M., Pisarenko P.V., Pisarenko V.V. (2008) Agroecology. Poltava (in Ukrainian).

Polishchuk, S.V. (2014) Features of manifestation of bacterial diseases on soya crops. Proceedings of the Scientific Research Center of the NAAS Institute of Agriculture Kyiv, 3, 108-115 (in Ukrainian).

Primak, I.D., Panchenko, O.B., Panchenko, I.A. (2018) Weediness and productivity of short-rotation agrophytocenoses of Right-Bank Forest Steppe of Ukraine under different systems of basic tillage and fertilization of typical black soil. Taurian Scientific Bulletin, 100(2), 39-50. (in Ukrainian).

Prymak, I.D. (2019), Mechanical tillage: history, theory, practice. Vinnytsia: TOV "Tvory" (in Ukrainian).

Storchous, I.M. (2013) Wheat treatment. Agribusiness today, 9, 37-40 (in Ukrainian).

Timofeev, V.P., Perfilyev, N.V., Vyushina, O.Ya. (2016) Phytosanitary state of spring wheat crops depending on the soil tillage system in the conditions of the Northern Trans-Urals. Agriculture, 2, 18-22 (in Ukrainian).

Tribel, S.O., Sigaryova, D.D., Secun, M.P. (2001). Methods of testing and application of pesticides. Kiev: The World (in Ukrainian). Tsylyuryk, O.I., Gorobets, A.G., Gorbatenko, A.I., Chaban, V.I., Gasanova, I.I., Sudak, V.M. (2012) The effectiveness of the shallow tillage system against the background of post-harvest residues and mineral fertilizers in rotation. Bulletin of the Institute of Agriculture of the steppe zone of NAAS of Ukraine, 3, 23-28.

\section{Citation:}

Prymak, I.D., Yakovenko, O.M., Voytovyk, M.V., Karaulna, V.M., Yezerkovska, L.V., Panchenko, O.B., Fedoruk, Yu.V., Pokotylo, I.A., Panchenko, I.A. (2020). Effect of soil treatments on pests contamination and crop disease distribution in black soil fields with short rotation crops. Ukrainian Journal of Ecology, 10(1), 127-132. 